\title{
Passado e identidade veiculado na imprensa: "Os construtores de SC" e o ensino de História (fevereiro de 1987) ${ }^{*}$
}

\author{
Luciana Rossato ${ }^{1}$ \\ Milene Chagas de Souza ${ }^{2}$
}

\begin{abstract}
Resumo: Nos dias 17, 18 e 19 de fevereiro de 1987 foi publicado pelo jornal Diário Catarinense o Caderno Especial "Os Construtores de SC" no qual são tratados aspectos da história e da cultura dos grupos étnicos que vivem no estado. Neste artigo analisaremos as imagens e discursos veiculados pela imprensa sobre o passado a fim de identificar as representações que são difundidas entre a população sobre a formação do estado. Estudos mostram que crianças e jovens adquirem conhecimentos sobre o passado em inúmeros espaços sociais o que contribui para a formação de sua consciência histórica, bem como influi em seu processo de aprendizagem.
\end{abstract}

Palavras-chave: Imprensa; identidade; grupos étnicos.

Abstract: On 17, 18 and 19 February 1987 was published by the newspaper Diario Catarinense Special Section "The Builders of SC" in which are treated aspects of the history and culture of the ethnic groups living in the state. In this article we will analyze the images and discourses in the press about the past in order to identify the representations that are widespread among the population about the formation of the state. Studies show that children and young people acquire knowledge about the past in numerous social spaces which contribute to the formation of its historical consciousness, as well as had an influence on their learning process.

Keywords: Media; identity; ethnic groups.

Mês de fevereiro, mês do carnaval. As notícias sobre esta festa circulam em diferentes âmbitos, sejam através de jornais, rádios ou mesmo no diálogo cotidiano das diversas pessoas que adoram, participam ou simplesmente detestam a principal festa popular do Brasil. Em meio a todas as notícias eufóricas sobre o carnaval, em fevereiro de 1987, o jornal Diário Catarinense publicou, durante uma semana, matérias com o título "Os Construtores de SC". Assim, em 17 de janeiro de 1987, em uma terça-feira, nas páginas 20 e 21 do jornal, os açorianos são o primeiro grupo abordado nesta perspectiva que coloca os imigrantes

\footnotetext{
* Artigo submetido em 06 de novembro/2012 e aceito para publicação em 09 de janeiro/2013.

${ }^{1}$ Doutora em História pela UFRGS, Professora do Departamento de História e do Programa de pós-graduação em História da Universidade do Estado de Santa Catarina - UDESC.

2 Graduanda em História da Universidade do Estado de Santa Catarina - UDESC. Bolsista de Iniciação
} Científica. 
contribuindo de maneira árdua e eficaz para o sucesso do desenvolvimento do estado de Santa Catarina. Nos dias seguintes são contemplados, sucessivamente os italianos, alemães, poloneses, holandeses, gregos, árabes e os negros.

É interessante analisar o conteúdo dessas reportagens, o período em que foram publicadas e qual era seu público-alvo. Em um mês em que há um grande contingente de turistas na cidade de Florianópolis, cabe analisar qual "imagem" de Santa Catarina quer ser veiculada para o visitante e quais são as abordagens históricas presentes para consolidar as imagens referentes a esses imigrantes que se fixaram no estado de Santa Catarina. Assim, as palavras utilizadas nas manchetes, "influências", "herança", "preservação", "original", "recomeço", "típico" e "tradição" são importantes para a análise, a fim de identificar qual o sentido e a maneira como são utilizadas e quais as visões de passado estão sendo salientadas por este órgão da mídia.

Através de reportagens veiculadas em um jornal de circulação diária, podemos analisar a pretensão de fazer uma "propaganda" do estado de Santa Catarina. Peter Burke em $A$ fabricação do Rei nos fala das estratégias desenvolvidas pelos responsáveis pela construção/divulgação da imagem de Luis XIV e de como elas, bem como a representação do rei, mudavam dependendo do contexto e dos interesses envolvidos. Neste estudo o autor aprofunda as relações entre arte e poder e como ocorre o processo de "produção, circulação e recepção das formas simbólicas" (BURKE, 1994: 13). A partir das reflexões de Burke temos como objetivo neste artigo refletir sobre as imagens que estavam sendo difundidas a partir da veiculação de um conjunto de reportagens especiais sobre os "construtores de Santa Catarina" em um jornal diário de grande circulação e durante a alta temporada. Pensamos que, além de divulgar a cidade para os turistas, estas reportagens contribuem para construir uma memória sobre o passado do estado para os que nele habitam.

De um modo geral, os repórteres recorrem para a escrita destas reportagens a relatos e memórias de diversas pessoas. Estas pessoas são as que guardaram algum objeto antigo, que pertenceu ao bisavô açoriano ou italiano; são as que possuem uma casa em alguma das cidades colonizadas e que de certa forma tornou aquela construção uma ligação com os imigrantes remanescentes e seus descendentes; ou então estudiosos como Nereu do Valle Pereira que recolheu materiais do Ribeirão da Ilha, localidade do sul da Ilha de Santa Catarina, formando o acervo do Museu Etnográfico do Ribeirão, fundado por ele em 1970.

\footnotetext{
Em Tempo de Histórias

Publicação do Programa de Pós-Graduação em História da Universidade de Brasília (PPGHIS/UnB) No. 23, Brasília, ago. - dez. 2013

ISSN 2316-1191
} 
O conceito de "lugares de memória" foi exaustivamente explorado pela historiografia recente e busca caracterizar o demasiado interesse de "lembrar" e "esquecer" da qual as sociedades atuais são afligidas, criando-se assim os chamados "lugares de memória", espaços físicos que tem como objetivo a rememorização. A partir desta discussão de Pierre Nora (1993) em relação aos "lugares de memória”, Peter Burke, no artigo "Quase memória" (Folha de São Paulo, 2008, p. 1) publicado no caderno Mais! salienta que, no Brasil, os principais lugares de memória não são espaços físicos como na Europa, mas sim o carnaval e as telenovelas. Segundo ele, através destes dois recursos a memória e o passado são resignificados. A partir da reflexão de Burke entendemos que os jornais de notícias também são espaços que contribuem para a construção e veiculação de memórias, como podemos perceber através do especial "Construtores de SC" abordado neste artigo.

Paul Ricouer, filósofo francês, estabelece uma relação entre a memória e a história importante para o ofício de historiador. A memória do passado pode ser alterada uma vez que "lembrar-se", para Ricoeur, "é apropriar-se da memória para fazer algo com ela" (Ricouer. apud REIS, 2010: 35). A análise de Ricouer é de suma importância para observar dos usos da memória do passado através das reportagens vinculadas no jornal Diário Catarinense.

Ricoeur analisa a memória em uma posição de não antagonismo com a história. Seu questionamento parte da distinção entre memória e imaginação, partindo do princípio que a primeira se diferencia absolutamente da segunda, mas não se separa. Enquanto o tempo da imaginação é leviano, pode ser inventado, modificado e confundido, o tempo da memória é fixo. Para a memória, no entanto, há sempre de se lembrar em "algum lugar" do passado onde determinada coisa está fixa, por mais confusa que esta memória esteja. Assim, a mesma possui o aspecto de pertencer sempre ao passado, nunca ao presente e ao futuro. Pode ser lembrada no presente e possuir um caráter pragmático para o futuro, entretanto ela é fixa em seu passado, diferente da imaginação, que por ventura pode se concentrar no futuro ou dialogar com o próprio presente, “a memória, ao contrário está voltada para a realidade anterior [...]. A memória é do passado, é o fenômeno da presença de uma coisa ausente, mas que esteve anteriormente aí” (Ricouer apud REIS, 2010: 33). Desta maneira, o uso da memória para a análise do passado não deve ser descartado. No entanto, devemos analisar as memórias dentro de seu contexto e momento, o passado.

Em um apanhado geral sobre os usos da memória para a história - nas suas mais 
diversas mudanças ao longo do século XX, Jacy Alves de Seixas aponta uma discussão que permeia o campo da teoria da história até hoje e que aparentemente ainda não foi "solucionada". Segundo a autora, "a adequação entre memória e história possui, portanto, raízes sólidas e longas" (SEIXAS, 2004: 39). Desta maneira, a visão de Nora do final do século XX é questionada e importantes estudos sobre a memória são resignificados, sendo a história oral uma fonte histórica muito utilizada nas últimas décadas.

O alargamento do significado de fontes históricas, a partir da segunda metade do século XX, possibilitou uma maior atenção à memória, como já dito, bem como aos jornais. As discussões em relação à legitimidade destes materiais para a operação historiográfica passou também por questionamentos ao longo do último século. Deste modo, as discussões acerca do material jornalístico passaram por diversas discussões, como demonstra Tânia de Luca, "reconhecia-se, portanto a importância de tais impressos e não era nova a preocupação de se escrever a História da imprensa, mas relutava-se em mobilizá-los para a escrita da história por meio da imprensa" (LUCA, 2005: 111).

Um dos grandes "impasses" da utilização dos jornais para a escrita da história, segundo o pensamento da historiografia dita tradicional, diz respeito ao seu caráter interligado com a falta de isenção ideológica por parte dos seus produtores. A crítica também era relacionada a outros aspectos que constituem a natureza de um material jornalístico: as diversas opções de selecionar o que é ou não publicado no jornal, a presença de propagandas publicitárias, o corpo editorial seletivo, além da própria escolha de títulos de reportagens, imagens, posição da matéria na página. Estes itens correspondem a um estudo de fonte necessário ao trabalhar com jornais. Ainda segundo Luca:

de fato, jornais e revistas não são, no mais das vezes, obras solitárias, mas empreendimentos que reúnem um conjunto de indivíduos, o que os torna projetos coletivos, por agregarem pessoas em torno de idéias, crenças e valores que se pretende difundir a partir da palavra escrita (LUCA, 2005: 140).

Tanto a memória como as fontes jornalísticas durante muito tempo gozavam de questionamento em seu estatuto como fonte histórica. Felizmente esta discussão avançou e ambos são entendidos como fontes privilegiadas para a escrita da história, ou, segundo Ricouer, para a operação historiográfica. Nossa principal problemática de pesquisa parte do 
entendimento que os impressos, tais como jornais diários, revistas semanais e mensais, etc. fazem circular, produzem e reelaboram memórias. Exemplo é o conjunto de reportagens especiais publicadas no DC no verão de 1987 no qual veiculam uma narrativa sobre o passado de SC e de seus "construtores".

\section{O Diário Catarinense}

Para começo de análise destas fontes, é necessário um breve histórico do jornal. $\mathrm{O}$ Diário Catarinense, fundado em 05 de maio de 1986, foi o último projeto idealizado pelo fundador do Grupo RBS, Mauricio Sirotsky Sobrinho, falecido em março daquele mesmo ano. No ano da primeira edição, havia em Florianópolis também o jornal "O Estado" fundado em 1915 e que, durante a década de 1970 e 1980, esteve entre os principais jornais de Santa Catarina, fechando em 2007. O Diário Catarinense é hoje o principal jornal do Estado de Santa Catarina, e faz parte do grupo RBS, que publica outros jornais e mantém uma emissora de televisão. Este grupo é hegemônico no Estado, sendo o principal veículo de comunicação da população catarinense, representado pelo canal da RBS Catarinense e a página do jornal na internet. Ao analisar as reportagens do Diário Catarinense, o historiador Igor Queiroz constatou matérias do próprio jornal a respeito a sua ampla comercialização no Estado. Com base na pesquisa de Ibope, o jornal elaborou a reportagem denominada "75 em cada 100 elegem o melhor", publicada em 05 de setembro de 1987:

De fevereiro a abril, 70 em cada 100 leitores de jornais da Grande Florianópolis optaram pelo Diário Catarinense, enquanto 52 tinham por hábito a leitura do jornal -B\|. De maio a julho, a preferência pelo Diário Catarinense cresceu para 75 em cada 100 leitores, e apenas 46 em cada 100 leitores optaram pelo jornal $-B$.

Estes dados confirmam uma tendência que sentimos em todo o mercado: cada vez mais as pessoas se identificam com o Diário Catarinense (QUEIROZ, 2011: 17).

Nos cinco primeiros anos do jornal, o DC raramente publicava fotografias coloridas, sendo reservada, quando apareciam, a primeira página ou a última. Em relação às oito matérias do conjunto "Os Construtores de Santa Catarina" nenhuma das páginas possui foto colorida, exceto algumas páginas de contracapa que as utilizavam como um chamariz para a reportagem a ser publicada na edição seguinte. Os sete primeiros grupos (açorianos, italianos,

\section{Em Tempo de Histórias}

Publicação do Programa de Pós-Graduação em História da Universidade de Brasília (PPGHIS/UnB)

No. 23, Brasília, ago. - dez. 2013

ISSN 2316-1191 


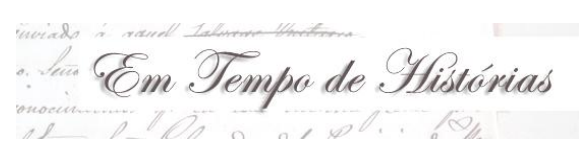

alemães, poloneses, holandeses, gregos e orientais) ganham destaque com matéria apresentada em duas páginas inteiras, com imagens em preto-e-branco e alguns textos. O último grupo, os negros, é apresentado somente em uma página e encerrando a série de matérias em uma terçafeira, dia 24 de fevereiro de 1987. A elaboração dos textos é realizada por diferentes pessoas, que escreviam das cidades onde o grupo imigrante se fixou, como por exemplo, os açorianos. Rose Delfino, a jornalista que escreve esta reportagem, aparentemente está em Florianópolis. Em contrapartida, Nádia Couto, ao escrever sobre os imigrantes italianos, escreve de Criciúma. Assim, cada jornalista escreve das cidades onde os imigrantes se instalaram majoritariamente.

Para este artigo, foram escolhidos para uma abordagem mais aprofundada os três primeiros grupos: açorianos, italianos e alemães. Ao longo do século $\mathrm{XX}$, os discursos empreendidos acerca destes grupos sofreram modificações de acordo com o período político e a sua intenção de exaltá-los ou negá-los. ${ }^{3}$ No entanto, em meio às discussões em torno destes três grupos, outras populações que constituem o território catarinense não ganham voz nesta historiografia de cunho mais tradicional, representada por Oswaldo Cabral e Walter Piazza, como por exemplo, os grupos indígenas e as populações afrodescendentes. Em meio à exclusão social de tais grupos, este ato reverbera nos discursos historiográficos que invisibilizam as ações destas populações no processo histórico de transformação do território catarinense. Assim, a invisibilização pela historiografia se dá, no momento em que se coloca a civilidade europeia - seja ela pela cultura açoriana ou alemã - como um fator de homogeneização da cultura catarinense, ocultando as outras populações que também fazem parte da "cultura catarinense", como salientam o historiador Paulino Cardoso e a historiadora Cláudia Mortari: “sem dúvida o debate sobre as populações do litoral catarinense não é novo e se confunde com a chegada do discurso científico nestas paragens entre o final do século XIX e as primeiras décadas do nosso século." (CARDOSO; MORTARI, 2001: 84).

Os diversos debates que pipocaram a partir da década de 1980, decorrentes de dos movimentos políticos em diferentes âmbitos trouxeram uma nova perspectiva ao estudo das

\footnotetext{
No período varguista, os imigrantes alemães sofreram repressões por sua ligação ao seu país de origem. A busca de uma identidade nacional, a língua alemã fora proibida e o ensino particular ligado a famílias de origem germânica também foram impedidas de continuar lecionando. Ver: BRANCHER, Ana Lice. História de SC:estudos contemporâneos. Florianópolis: Letras Contemporâneas, 1999. BRANCHER, Ana Lice \& AREND, Silvia (orgs.). História de SC no século XIX. Florianópolis: UFSC, 2001.
}

\section{Em Tempo de Histórias}

Publicação do Programa de Pós-Graduação em História da Universidade de Brasília (PPGHIS/UnB)

No. 23, Brasília, ago. - dez. 2013

ISSN 2316-1191 
populações afro-descendentes e indígenas. Esses grupos étnicos que eram invisibilizados na produção historiográfica e discursiva referente a Santa Catarina, a partir de 1980, ganham voz e lhe são atribuídos novos significados. Dentre estes movimentos pode-se citar os movimentos por igualdade racial e por igualdade de gênero que ganharam espaço na segunda metade do século XX. Portanto, podemos destacar dentre os novos debates, estudos mais sistemáticos sobre as populações africanas e os grupos indígenas.

A partir destas novas discussões, atentamos a esta preocupação de rememorialização de uma cultura ou de múltiplas culturas que contribuíram para a formação do catarinense. É perceptível que o discurso do jornal $O$ Diário Catarinense no ano das matérias em análise (1987), reverberam uma mescla de "cuidado com o antigo", com uma perspectiva de salvaguardar uma "cultura" que estaria se perdendo, sendo assim necessário relembrar essas ditas tradições.

Assim, a primeiro excerto que apresenta da série de reportagens é:

O Homem tipo catarinense ainda está em formação e será o resultado produzido por um caldeirão cultural onde misturam-se influências de diversas nacionalidades, com predominância de açorianos e alemães, mas com a inclusão também de gregos e árabes. Este movimento, que acabará por formar o catarinense, recebe, a partir de hoje, a contribuição histórica de uma série de reportagens publicadas pelo DC (DIÁRIO CATARINENSE, 17 de fevereiro de 1987: 20).

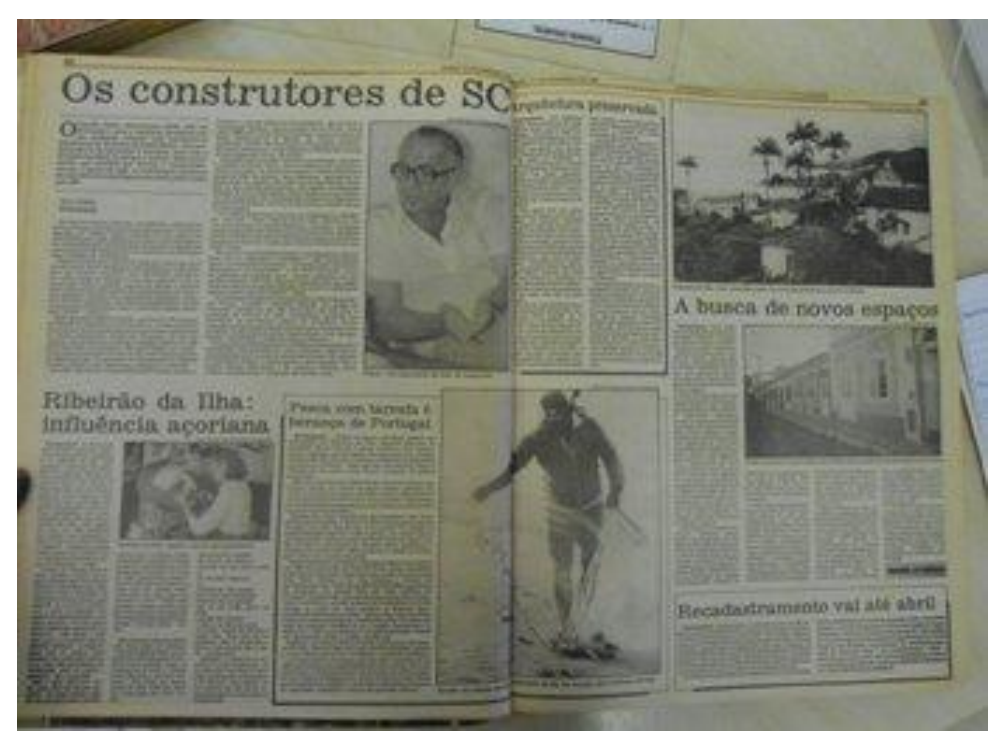

Figura 1: Diário Catarinense, 17.02.1987. p. 20 e 21. Acervo: Biblioteca Pública do Estado de Santa Catarina. Foto: Milene Chagas de Souza. 
Logo abaixo deste excerto, há uma breve explicação do historiador Walter Piazza acerca da vinda das populações imigrantes para Santa Catarina em um contexto mais geral. A reportagem trás dados colocados por Piazza, que contam em números e datas a instalação dos imigrantes, bem como descreve a situação europeia que levou estas populações a emigrarem.

Na opinião do historiador Piazza, os imigrantes vinham para vencer, dispostos a trabalhar e não encontraram apoio e orientação do governo. "As imigrações não foram planejadas e os imigrantes - com raras exceções, como os alemães da segunda leva - foram entregues ao seu próprio destino. Por isso algumas experiências que poderiam ter sido interessantes não deram certo e o sofrimento desnecessário não foi evitado", disse.

Um exemplo evidencia e fundamenta a crítica do professor Piazza. Durante o segundo império, um grupo de franceses instalou-se em São Francisco do Sul com a proposta de formar ali uma comunidade baseada nos princípios do socialismo utópico de Proudhon. Eram artesãos e artistas que não encontraram o mercado para seus produtos, dedicaram-se então à agricultura, mas, inexperientes, desistiram e voltaram para a França (DIÁRIO CATARINENSE, 17 de fevereiro de 1987: 20).

A partir deste excerto, há o reforço a imagem do imigrante que lutou contra todas as adversidades para vencer. Ao chegar ao território catarinense, os mesmos depararam-se com o espaço onde tinham que se instalar. No entanto, as condições eram terríveis: mata fechada, falta de comida, etc. Não cabe aqui julgar se as necessidades são legitimas ou não, mas sim ponderar estas dificuldades em relação aos outros povos que viviam no território catarinense anteriormente a vinda dos imigrantes e as implicações políticas que este discurso exaltado reverbera. Além do mais, havia outras populações que viviam nestes territórios antes da vinda dos imigrantes europeus. As populações indígenas tanto do litoral como da região do vale tiveram que assistir a chegada destes novos "estranhos". No entanto, a população indígena nem mesmo é citada nesta empreitada imigrante e quando o é, é citada pejorativamente, muitas vezes considerada "empecilho" para a efetiva instalação dos imigrantes. Neste sentido, os indígenas foram um obstáculo a ser removido para a eficácia da imigração. Esta questão coloca-se muito forte quando se trata dos imigrantes alemães na região de Blumenau, como trabalharemos adiante. Segundo a historiadora Maria Bernadete Ramos Flores, ao analisar os discursos de exaltação do açoriano a partir do Primeiro Congresso da Colonização Açoriana em 1948,

não se fala do "homem do litoral", de uma perspectiva pessimista, como 
homem "indolente e incapaz", mas se fala do "açoriano" (o mesmo homem ontológico e biológico) como aquele que, historicamente, deu seu sangue, sua vida, sua bravura, sua história na construção da brasilidade de Santa Catarina (FLORES, 1997: 133).

É interessante analisar que este discurso do final da primeira metade do século XX analisado por Flores - ainda está interligado, em termos, com a década de 1980, já que Piazza considera como uma grande "aventura" a vinda dos açorianos, que driblaram com ardor e eficácia as dificuldades que tiveram ao se estabelecer, exaltando a capacidade deste grupo de lidar com as dificuldade ao chegar em terras catarinenses.

Seguindo a reportagem sobre os açorianos, localizada no dia 17 de Fevereiro de 1987, na página 20 e 21 ainda coloca os seguintes manchetes: "Ribeirão da Ilha: influência açoriana" e "Pesca com tarrafa é herança de Portugal", "Arquitetura preservada", "A busca de novos espaços" e ainda "Recadastramento vai até abril." As três primeiras manchetes trazem uma tradição que ainda perdura, se colocadas assim em termos simplificados. "A cultura açoriana também pode ser observada no dia-a-dia da comunidade do Ribeirão da Ilha, onde podemos encontrar três gerações fazendo rendas de bilro" (DIÁRIO CATARINENSE, 17 de fevereiro de 1987: 20).

Não cabe aqui analisar se estas práticas são "verdadeiras" ou "tradições inventadas", mas cabe colocar de que maneira são resignificadas, colocadas como pertencentes ao presente, mas também como estanques em seu próprio tempo, como se estas práticas não se transformassem. Podemos analisar então este excerto colocado acima, que põe a renda de bilro como praticada por três gerações, interruptamente e de forma igualitária por estas três mulheres, pertencentes a três temporalidades diferentes. No entanto, mais a frente, a reportagem irá colocar que outra "mulher" vem pegar estas rendas de bilro no bairro do Ribeirão da Ilha com as produtoras do bilro e vendê-las na Rua das Rendeiras, no bairro da Lagoa da Conceição. Segundo uma das rendeiras: "vendemos nossas rendas para uma mulher que revende para os turistas na Lagoa da Conceição". (DIÁRIO CATARINENSE, 17 de fevereiro de 1987: 20). O significado do feitio da renda de bilro modificou-se. Se anteriormente a produção das rendas se dava para a sua utilização nas casas destas mulheres, neste momento ela é produzida para a venda turística. Perdeu-se um significado e colocou-se outro. No entanto, o discurso coloca como uma continuidade, uma estagnação, uma tradição. 
Segundo Maria Bernadete Ramos Flores: “A rememoração que se dá num presente, pode ser de algo que tenha sido interrompido no passado, sem continuidade com o presente, apagado na memória oral" (FLORES, 1997: 119).

Os exemplos se seguem:

Muitas das festas folclóricas dos açorianos são ainda celebradas na região. O terno de Reis começa na passagem de ano e vai até o dia de reis, 6 de janeiro. Um grupo de músicos tocando tambor, violão e rebeca - um violino rústico de duas cordas - visita as casas cantando músicas improvisadas na hora e que falam da situação, problemas e alegria da comunidade. Mais suntuosa é a festa do Divino, que ocorre em meados de Junho.

$[\ldots]$

Segundo o professor Nereu Pereira o isolamento do Ribeirão da Ilha, distante $38 \mathrm{~km}$ do centro de Florianópolis, ajudou a comunidade a preservar hábitos e costumes açorianos. "A energia elétrica só chegou aqui em 1958, o telefone só em 1980 e apenas 5 anos temos ônibus de hora em hora. Foi esse isolamento o responsável pela manutenção da cultura popular que começa a desaparecer, já que os jovens estão saindo para trabalhar na cidade e a televisão uniformiza as formas de expressão, impondo a cultura dos grandes centros (DIÁRIO CATARINENSE, 17 de fevereiro de 1987: 20). [grifos meus]

Percebemos pelos trechos acima, que pertencem à manchete "Pesca com tarrafa é herança de Portugal", que além da renda de bilro, o terno de reis e a festa do divino são heranças açorianas que se perpetuam com a imigração. Este é o discurso difundido pelo jornal. O segundo trecho é ainda mais emblemático, por tratar da fala de um sociólogo que vive no Ribeirão da Ilha, Nereu Pereira, que afirma que esta preservação dos "hábitos e costumes açorianos" deu-se por conta do isolamento do bairro, mantendo-se assim, intacto por anos e anos. A crítica incide aqui mais uma vez no discurso de que estes costumes estão estanques no tempo, não se modificando. A justificativa de Pereira não isenta o grupo, que por mais que esteja "isolado" do resto da Ilha, de modificar os costumes e hábitos com a herança 
dos Açores a partir da sua nova experiência na Ilha. Emblemático também, no fim da fala de Nereu Pereira que transmite certo pessimismo e até uma crítica acerca desta quebra do isolamento do Ribeirão da Ilha. Com a ligação facilitada do bairro a outras partes da Ilha, como o advento de novas tecnologias no Ribeirão, esta cultura, que antes estaria intacta, está se transformando, não se tornando mais "pura", o que significa para Pereira um lamento. Como coloca Ortiz, em uma passagem emblemática: "a tradição procura paralisar a história, invocando a memória coletiva como instituição privilegiada de autoridade - 'os costumes existem desde sempre"” (ORTIZ, 1994: 183).

Tradição também é o termo utilizado para falar dos costumes italianos e alemães que envolvem estes povos. No dia 18 de Fevereiro, é a vez da reportagem sobre o segundo grupo dos "Construtores de Santa Catarina": os italianos. A manchete principal diz: "A saga italiana em terras catarinenses", traz nas páginas 20 e 21 textos com as seguintes manchetes: "Agente do Consulado pesquisa a história", "Tradição de pai para filho desde o começo" e "Urussanga, no Sul: o berço da colonização". Os textos tratam, em sua maioria de dados que remetem a colonização dos povos italianos em cidades catarinenses. É retratado a partir do número de imigrantes e as diversas levas de emigração deste povo para Santa Catarina. Deste modo, os imigrantes italianos fundaram e desenvolveram cidades, mais uma vez sem muito apoio estatal. Nádia Couto, escrevendo na cidade de Criciúma, conta como foi à fundação de tal cidade:

O padre Luigi Marzano, que residiu no município de Urussangra no ano de 1899, manteve contatos com vários imigrantes da região e publicou em 1904, na Itália, a obra "Colonos e Missionários Italianos nas Florestas do Brasil". No livro, ele conta os problemas enfrentados pelos colonos. Quando esse segundo grupo de italianos chegou a Urussanga, relata o padre, um agenciador da imigração, temendo a força que adquiriram os imigrantes, decidiu suspender a concessão de terras, mandando-os para a floresta, a 25 km ao sul do município.

Foi fundada então a Colônia de Criciúma. O caminho consistia em uma picada estreita, ao longo de um curso d'água, e os italianos passaram a primeira noite num barracão. "Eles estavam em meio a uma grande floresta, ninho de selvagens e de animais ferozes, sem armas, sem amigos e 
sem ajuda. Em geral, todos estavam arrependidos por terem dado esse passo. Não havendo mais tempo para remedir, precisavam adaptar-se. Aqui estão com que duras provas foram fundadas as colônias italianas no Brasil” (DIÁRIO CATARINENSE, 17 de fevereiro de 1987: 20). [grifos meus]

Uma das fontes desta colunista é um livro de memórias do padre Marzano, publicado no ano de 1908. O excerto selecionado pela jornalista também coloca uma série de impedimentos que os imigrantes italianos tiveram que ultrapassar, e assim, a partir de todo o esforço, fundaram Criciúma.

Esta edição do dia 18 de fevereiro compartilha também, na página 20, uma notícia intitulada 'Tradição de pai para filho desde o começo' e cabe citar um trecho bastante significativo:

A tradição ainda é mantida na família Fontana. A serraria construída em 1901 pelo bisavô Giacomo foi passada de pai para filho, até chegar a Galdino Fontana. Hoje com 58 anos, ele é aposentado, mas continua trabalhando com a madeira. O avô de Galdino, Sebastião Bez Fontana, veio para o Brasil [...].

Chegando a Urussanga, a família teve que abrir picadas na mata, como todos os outros imigrantes. O cenário atual do sítio dos Fontana, uma área de terra com 35 hectares [...] guarda todas as características da época. A roda d'Água ainda funciona, o oratório localizado na frente do sítio permanece intocado e a casa de madeira crua é a mesma que Giacomo construiu no início do século.

Internamente, tudo lembra a origem da família. Há vários móveis feitos na serraria [...] Num canto da sala, um videogame quebra o clima de tradição, registrando os novos valores da família.

Os filhos de Galdino e Olga Fontana são jovens - o mais velho tem 29 anos e o caçula 15. "Nenhum deles, salienta o pai, se interessa pelo sítio." Em nenhum deles Galdino sente a intenção de manter a serraria, preservar as origens. "Hoje a juventude não valoriza muito isso", lamenta ele (DIÁRIO CATARINENSE, 18 de fevereiro de 1987: 20). [grifos meus] 
Podemos perceber neste trecho o desejo de manter a tradição que a família diz ser muito antiga. A temporalidade desta tradição mostra-se estanque, visto que a serraria continua "intacta”, com os aspectos da época, como os móveis da família feitos na tal serraria. É interessante a passagem: "O cenário atual do sítio dos Fontana, [...] guarda todas as características da época.” (DIÁRIO CATARINENSE, 18 de fevereiro de 1987: 20). O cenário atual é um cenário que remete a uma época distante, mas, no entanto nele também está abrigado as modificações que a família fez ao longo de sua estadia ali. Como a chegada do videogame, que para a jornalista "quebra" a tradição, além do lamento dos pais do garoto em não conseguir fazer brotar o interesse de seus filhos na serraria. Segundo Zanella, "inventa-se assim a tradição, criando rituais que buscam a memória, parecendo estabelecer uma ligação entre o passado e o presente" (ZANELLA, 1999: 94). A função da serraria ou da roda d'água seria, na época em que foi construída no terreno da família, uma questão de praticidade e necessidade. No entanto, este sentido modifica-se. Galdino, o pai da família, tenta manter esta serraria como uma forma de lembrar-se de seus antepassados, assim como outros elementos pertencentes aos seus antecessores, como os móveis. Assim, além da função do objeto em si, Galdino agrega a estes o caráter de rememoração do passado.

$\mathrm{Na}$ reportagem do dia 19 de fevereiro, trata dos alemães. O chamariz principal é o seguinte: “A contribuição alemã à história catarinense.". Mas que história é essa vinculada pela edição? Coloca-se que a principal contribuição deste grupo se deu na economia e na cultura. A primeira está ligada ao setor industrial, onde, segundo o jornal, os imigrantes já "conheciam" a industrialização europeia e para cá trouxeram consigo, favorecendo a fundação, o 'desenvolvimento', a urbanização e o crescimento da cidade de Blumenau, principal cidade de colonização alemã. Segundo o jornal: “A intenção do Dr. Blumenau, fundador da cidade, era transformar a colônia num grande centro de trabalho e prosperidade (...)" Já se contava, em princípio, com o desenvolvimento da colônia, assim: “Os imigrantes trouxeram das zonas europeias já industrializadas a técnica e a habilidade para transformar a colônia num dos maiores pólos industriais do Brasil” (DIÁRIO CATARINENSE, 19 de fevereiro de 1987: 20).

Mas aí, em meio aos discursos de positivação deste grupo, há uma notícia neste ínterim muitíssimo interessante a qual me referi anteriormente. É a questão dos grupos indígenas, que 
finalmente aparecem em algum lugar neste conjunto de reportagem. Mas digo que a visão não é positivada, vitimizada ou em defesa a estes grupos. A visão é a de "empecilho". Há trechos emblemáticos desta questão, presentes na notícia intitulada "Competições de Tiro surgiram por esporte e medo dos índios":

Os clubes de tiro para os alemães significam bem mais do que a satisfação com um disparo certeiro. Para os descendentes desse povo, esses clubes são a memória viva dos seus antepassados e das suas terras de origem, onde originou-se a tradição do Schutzenfest (as competições de tiro). Essas disputas surgiram em Santa Catarina com os primeiros imigrantes que colonizara a região do Vale do Itajaí Açu. Primeiramente, o hábito de se armar apareceu como reação aos ataques indígenas e mais tarde, quando os imigrantes iam às compras, nos domingos e feriados. No meio do caminho, eles se encontraram e testavam suas pontarias em um alvo improvisado (DIÁRIO CATARINENSE, 19 de fevereiro de 1987: 20).

Os grupos indígenas serão o grande empecilho para o desenvolvimento das colônias alemãs, segundo os discursos do início do século XX. Neste trecho acima, os grupos indígenas que viviam na região do Vale, os Xokleng, são a ameaça que teima em atacar os alemães. A nova historiografia, a partir de 1980, como já foi relatada, busca produzir outras narrativas a partir destes acontecimentos e dar voz a estes agentes históricos. Um exemplo é a obra da historiadora Luisa Wittmann, O Vapor e o Botoque, que nos apresenta outra versão sobre o embate entre os alemães e os Xokleng na metade do século XIX e início do XX na região do Vale do Itajaí. Wittmann tenta, a partir da análise de documentos oficiais e jornais da região, construir uma narrativa no qual apresenta a visão alemã sobre os indígenas, mas também busca uma visão “indígena”. Não uma visão vitimista que retrata os grupos indígenas como vítimas deste sistema, mas sim como grupos que possuíam suas aspirações, desejos e medos. Assim, estes grupos viviam nestas terras e assistiram a vinda dos alemães. Como eles reagiram e talvez porque agiram de determinada forma, é o que Wittmann busca compreender, indo além da vitimização ou dos pensamentos de selvageria e civilidade.

Como dito anteriormente, o conjunto de reportagens do DC retrata o histórico da vinda e instalação de oito populações ao estado catarinense. Em um recorte simplificado, os três 
primeiros grupos foram retratados aqui. E ainda mais, foi feito um recorte dentro destes três reportagens, dos dias 17, 18 e 19 de fevereiro de 1987, nas páginas 20 e 21 do Diário Catarinense.

A memória é exaltada em algumas partes do discurso jornalístico. Para este, o legitimando, conferindo tom de verdade a reportagem. O conteúdo ali apresentado, é visto como uma única via, diante disto, podemos perceber que nos fins da década 1980, muitos discursos de cunho tradicional ainda estão enraizados nestes escritos jornalísticos, no qual culturas são colocadas como estagnadas no tempo, culturas que se remodelam a cada dia, a cada mês ou a cada ano. Culturas múltiplas, que muitas vezes são resumidas a uma prática cultural simplificada e repetida sem questionamentos.

Este discurso único e invisibilizante coloca, em pleno carnaval catarinense, um discurso que irá atingir não somente os moradores locais ou simplesmente a população catarinense, mas também, o turista, um contingente de pessoas que visitam a cidade e ocasionalmente leem o jornal; deste modo, o discurso ganha maior amplitude. Destarte, o importante não é negar todos esses discursos, mas sim questiona-los, pois assim, não criamos uma história homogênea e que visibiliza somente alguns, mas todos.

\section{Fontes}

Diário Catarinense, 17 de Fevereiro de 1987. P. 20, 21.

Diário Catarinense, 18 de Fevereiro de 1987. P. 20, 21.

Diário Catarinense, 19 de Fevereiro de 1987. P. 20, 21.

Acervo: Biblioteca Pública do Estado de Santa Catarina

\section{Referências Bibliográficas}

BURKE, Peter. A fabricação do rei: a construção da imagem pública de Luís XIV. Rio de Janeiro: Jorge Zahar Ed., 1994.

CAMPOS, Cynthia Machado. As intervenções do Estado nas escolas estrangeiras de Santa Catarina na Era Vargas. In: BRANCHER, Ana (org.). História de SC: estudos contemporâneos. Florianópolis: Letras Contemporâneas, 1999.___ \& AREND, Silvia (orgs.). História de SC no século XIX. Florianópolis: UFSC, 2001.

CARDOSO, Paulino de Jesus; MORTARI, Cláudia. Territórios negros em Florianópolis no Século XX. In: BRANCHER, Ana (org.). História de SC: estudos contemporâneos. Florianópolis: Letras Contemporâneas, 1999.__ \& AREND, Silvia (orgs.). História de SC no século XIX. Florianópolis: UFSC, 2001.

FLORES, Maria Bernadete Ramos. A Autoridade do Passado. In: A farra do boi: palavras, sentidos e ficções. Florianópolis: Ed. da UFSC, 1997.

\section{Em Tempo de Histórias}

Publicação do Programa de Pós-Graduação em História da Universidade de Brasília (PPGHIS/UnB)

No. 23, Brasília, ago. - dez. 2013

ISSN 2316-1191 
HOBSBAWM, E. J; RANGER, T. O. A invenção das tradições. 2. ed. Rio de Janeiro: Paz e Terra, 1997.

LUCA, Tânia Regina. A história dos, nos e por meio dos periódicos. In: PINSKY, Carla Bassanezi (org.). Fontes Históricas. São Paulo: Contexto, 2005.

NORA, Pierre. Entre memória e história: a problemática dos lugares. Projeto História, S.Paulo, n.10, p.7-28, dez. 1993. Disponível em: 〈http://www.pucsp.br/projetohistoria/downloads/revista/PHistoria10.pdf>.

Acesso em 4 Nov. 2012.

ORTIZ, Renato. Mundialização e cultura. 2. Ed. São Paulo: Brasiliense, 1994.

QUEIROZ, Igor Henrique Lopes de. Sujeitos a ou sujeitos de: as orientações sexuais desviantes nas páginas do jornal Diário Catarinense (1986-1988). 201178 p.: TCC (graduação) - Universidade do Estado de Santa Catarina, Centro de Ciências Humanas e da Educação, Curso de História, Florianópolis, 2011. Disponível em: <http://www.pergamumweb.udesc.br/dados-bu/000000/000000000013/00001349.pdf>. Acesso em: 16 de Junho de 2012.

REIS, José Carlos. O desafio historiográfico. Rio de Janeiro: Ed. da FGV, 2010.

SEIXAS, Jacy Alves de. Percursos da memória em terras de História: Problemáticas atuais. IN: BRESCIANI, Stella; NAXARA, Márcia. Memória e (res)sentimento: indagações sobre uma questão sensível.Campinas: Ed. da UNICAMP, 2004.

WITTMANN, Luisa Tombini. O vapor e o botoque: imigrantes alemães e índios Xokleng no Vale do Itajaí / SC (1850-1926). Florianópolis: Letras Contemporâneas, 2007.

ZANELLA, Cláudia Cristina. Atrás da porta: o discurso sobre o turismo na Ilha de Santa Catarina (1983-1998). Florianópolis, UFSC, 1999, (Dissertação de Mestrado em História). 